\title{
Prevalence of Pap smear abnormalities among women who attend Sexually Transmitted Diseases (STD) clinic, Colombo
}

\author{
Karawita $\mathbf{D A}^{1}$, Wijayawickrama $\mathbf{D N}^{1}$
}

\begin{abstract}
Introduction: Cervical cancer ranks as the second most frequent cancer among women in Sri Lanka. It has been now well established that oncogenic subtypes of human papillomavirus (HPV) is a necessary cause of cervical cancer. An abnormal Pap smear may indicate an infection, inflammation or cervical cytological abnormality.
\end{abstract}

Objectives: The objective of this study was to ascertain the prevalence of Pap smear abnormalities among women who attend Sexually Transmitted Disease (STD) clinic, Colombo

Method: A total of 1300 females who underwent routine Pap smear screening at STD clinic, Colombo in the year 2010 and 2011 were analysed for the prevalence of all forms of Pap smear abnormalities including cervical cytological abnormalities. Cytology was interpreted according to the national guideline which is based on Bethesda system 2001.

Results: Prevalence of all forms of abnormal Pap smears was $24.2 \%$ while the prevalence of cervical cytological abnormalities was only $2.2 \%$ in the sample, out of which $1.4 \%$ were low grade squamous intraepithelial lesions (LGSIL), $0.5 \%$ were high grade squamous intraepithelial lesions (HGSIL) and $0.3 \%$ were glandular cell atypia. The cervical cancer prevalence in the sample was $0.077 \%$.

Conclusions: All forms of Pap smear abnormalities among STD clinic attendees were relatively high $(24.2 \%)$ due to concurrent infections and inflammation. The rate of cervical cytological abnormalities was $2.2 \%$ while the cervical cancer rate was $0.077 \%$ in the sample. There was no significant difference between groups with and without cervical cytological changes.

Key words: prevalence, cytology, cervical cancer, epithelial cell abnormalities, sexually transmitted infections

\section{Introduction}

Cervical cancer is the second most common cancer in women worldwide and every year 530,000 new cervical cancer cases are diagnosed and more than 270,000 women die from cervical cancer; More than $85 \%$ of these deaths are in low and middle income countries. (1)

According to the Cancer Registry in Sri Lanka, the incidence of cervical cancer for the year 2005 was reported as $16 / 100,000$ population $(0.016 \%)$. It is the second commonest cancer among females and accounts for $12.1 \%$ of all cancers among women. (2)

Almost all cases of cervical cancer are caused by specific types of human papillomavirus (HPV). There are more than 100 types of HPV, of which more than 40 can be sexually transmitted. Among these, about 15 are considered to be cancer-causing or high risk types. Two of the high risk types, HPV-16 and HPV-18, cause about $70 \%$ of cervical cancers worldwide. HPV infection is common, but it usually goes away on its own. Persistent HPV infections can cause cellular dysplasia that sometimes develops into cervical cancers if not treated. (3)

\footnotetext{
${ }^{1}$ National STD/AIDS Control Programme, Ministry of Health, Sri Lanka

Corresponding author: Karawita DA, Email: ajith.karawita@gmail.com
} 
HPV is a sexually transmitted infection. Therefore, it is important to have close look at the cervical cytological changes among women attending sexually transmitted infection clinics. The objective of this study was to identify the prevalence of Pap smear abnormalities among women attending sexually transmitted disease clinic, Colombo.

\section{Screening for cervical cancer}

Screening for cervical cancer by analysing a sample of cervical epithelial cells is one of the great success stories in cancer prevention. The method was first launched for American women in 1950s, after George Papanicolaou, MD., a Cornell University Physician who developed a cervical smear screening test. (4) The method of cervical cells sampling and preparation techniques as well as the interpretation of cytological abnormalities evolved over the years. The 1988 Bethesda system which was developed by the National Cancer Institute (NCI), USA has been widely adopted (5) and was later updated in 2001 incorporating scientific evidence and clarifying controversial areas. Now it is the 2001 Bethesda system that is being used and adopted widely for the interpretation of cervical cell abnormalities.

In Sri Lanka, Cervical cytology screening in STD clinic setting was first introduced as a pilot study on the $2^{\text {nd }}$ of July 1986 to the Central Venereal Disease Clinic (CVDC) in Colombo. Furthermore, the study recommended the need of cervical cytology screening in STD clinic settings in the country and routine cervical cytology screening of female STD clinic attendees was started in late 1988 (6) In 1996, Family Health Bureau of the Ministry of Health started well woman clinics (WWCs) and cervical cytology screening was gradually incorporated in to the WWC setting. The principal target group of the WWC is the women over 35 years of age. In 2010, there were 815 WWCs functioning throughout the country. Of them only $676(83 \%)$ WWCs were equipped with Pap smear facilities.

\section{Methodology}

A cross sectional descriptive study design was used and the study was conducted in the Central STD Clinic, Colombo which is the main STD clinic located in the headquarters (HQ) of the National STD/AIDS Control Programme (NSACP). NSACP is the main government programme responsible for prevention, control, treatment and care of sexually transmitted infections including HIV. It has a network of 30 STD clinics and 29 branch clinics in the country. The 5year average annual new patient turnover of the central STD clinic, Colombo for males and females were 2052 and 1415 respectively. Almost all eligible females attending the Colombo STD clinic are offered Pap smear as a routine test. Pap samples are collected by gently scraping the circumference of the squamo-columnar junction using a wooden spatula by trained medical officers of STD. Materials collected on the spatula are quickly and evenly spread over the slide by flat motion. Then the slide is immediately fixed by immersing the slide in a Coplin's jar filled with $95 \%$ ethanol. Specimens are wet fixed in alcohol for 30 minutes, taken out, allowed to dry for a few minutes and then transported to the laboratory for reading. Smears are routinely read by a trained Medical Laboratory Technologist (MLT) and smears with pre malignant and malignant changes are sent to the pathologist for further evaluation.

Records of all female patients who underwent Pap smear screening at STD clinic from the $1^{\text {st }}$ of January 2010 to the $31^{\text {st }}$ of December 2011 were included as subjects in the study $(\mathrm{N}=1300)$. Data were extracted from the individual patient records. Patient record in the clinic is a well structured set of variables with properly coded values designed to be used for data entry purpose for the electronic Patient Information Management System (PIMS) of the clinic. \{The data quality is assured through two levels of supervision, immediate corrections by senior medical officer-1 (SMO-1) and subsequently the patient record is being supervised and finalized by senior medical officer- 2 (SMO-2) before sending for data entry.\} Cytology was interpreted according to the guidelines of Sri Lanka College of Pathologists and Sri Lanka College 
of Obstetricians and Gynaecologists which are based on 2001 Bethesda system. Data were analysed using SPSSv16 for descriptive statistics and possible predictors of abnormal cytology were examined by using binary logistic regression.

\section{Results}

\section{Socio-demographic characteristics}

There were 1300 records. Mean age was 34.6 years (SD, 10 years) and $81 \%$ had more than five years of school education. Over $63 \%$ of the sample were married or living with a stable partner. Age at coitarche of half of them $(49.4 \%)$ was less than 20 years. Half the sample was unemployed $(50.5 \%)$ while $22 \%$ reported that commercial sex work (CSW) as their occupation and 3.5\% were massage parlour or night club workers (Table 1)

Table 1: Socio-demographic characteristics and status of contraceptive use

\begin{tabular}{|c|c|c|c|}
\hline \multirow[t]{11}{*}{ Age groups } & $15-19$ & 46 & $3.5 \%$ \\
\hline & $20-24$ & 184 & $14.2 \%$ \\
\hline & $25-29$ & 210 & $16.2 \%$ \\
\hline & $30-34$ & 253 & $19.5 \%$ \\
\hline & $35-39$ & 195 & $15.0 \%$ \\
\hline & $40-44$ & 185 & $14.2 \%$ \\
\hline & $45-49$ & 124 & $9.5 \%$ \\
\hline & $50-54$ & 64 & $4.9 \%$ \\
\hline & $55-59$ & 23 & $1.8 \%$ \\
\hline & $\geq 60$ & 16 & $1.2 \%$ \\
\hline & Total & 1300 & $100 \%$ \\
\hline \multirow[t]{3}{*}{ Age } & $<35$ years & 693 & $53.3 \%$ \\
\hline & $\geq 35$ years & 607 & $46.7 \%$ \\
\hline & Total & 1300 & $100 \%$ \\
\hline \multirow[t]{4}{*}{ Marital status } & Single/Never married & 115 & $8.8 \%$ \\
\hline & Married/Living together & 823 & $63.3 \%$ \\
\hline & Widowed/Separated/Divorced & 362 & $27.8 \%$ \\
\hline & Total & 1300 & $100 \%$ \\
\hline \multirow[t]{3}{*}{ Age at coitarche } & $<20$ years & 633 & $49.4 \%$ \\
\hline & $\geq 20$ years & 649 & $50.6 \%$ \\
\hline & Total & 1282 & $100 \%$ \\
\hline
\end{tabular}




\begin{tabular}{|c|c|c|c|}
\hline \multirow[t]{7}{*}{ Level of education } & $1-5$ grade & 151 & $11.6 \%$ \\
\hline & $6-10$ grade & 469 & $36.1 \%$ \\
\hline & GCE O/L & 356 & $27.4 \%$ \\
\hline & GCE A/L & 227 & $17.5 \%$ \\
\hline & Dip/Degree & 21 & $1.6 \%$ \\
\hline & No schooling & 76 & $5.8 \%$ \\
\hline & Total & 1300 & $100 \%$ \\
\hline \multirow[t]{8}{*}{ Occupation } & Unemployed & 646 & $49.8 \%$ \\
\hline & Student & 6 & $0.5 \%$ \\
\hline & Retired & 2 & $0.1 \%$ \\
\hline & Commercial sex work & 285 & $22.0 \%$ \\
\hline & Massage parlour workers & 42 & $3.2 \%$ \\
\hline & Night club workers & 4 & $0.3 \%$ \\
\hline & Employed & 312 & $24.1 \%$ \\
\hline & Total & 1297 & $100 \%$ \\
\hline \multicolumn{4}{|l|}{ Occupation as sex workers } \\
\hline \multirow{2}{*}{ and non-sex workers } & Others & 966 & $74.5 \%$ \\
\hline & Total & 1297 & $100 \%$ \\
\hline \multirow[t]{9}{*}{ Current contraceptive use } & No & 622 & $47.8 \%$ \\
\hline & IUCD & 77 & $5.9 \%$ \\
\hline & OCP & 99 & $7.6 \%$ \\
\hline & Condoms & 203 & $15.6 \%$ \\
\hline & Tubal ligation & 162 & $12.5 \%$ \\
\hline & Injections & 94 & $7.2 \%$ \\
\hline & Natural methods & 22 & $1.7 \%$ \\
\hline & Others & 21 & $1.6 \%$ \\
\hline & Total & 1300 & $100 \%$ \\
\hline \multirow[t]{3}{*}{ Current contraceptive users } & Hormonal contraceptive users & 193 & $14.8 \%$ \\
\hline & Others including non users & 1107 & $85.2 \%$ \\
\hline & Total & 1300 & $100 \%$ \\
\hline
\end{tabular}




\section{Sexual behaviours}

Over half of the women (51.4\%) had one lifetime partner and $48.6 \%$ had more than one lifetime partner. Number of lifetime partners was over 100 in about $14 \%$ of women. Distribution of number of partners during the last 3 months showed that $62.5 \%$ had a single partner while $17.8 \%$ had five or more partners. Overall, $72 \%$ had one partner during the previous 3 months while $28 \%$ had more than one partner in the reduced sample of those who had partners last 3 months (Table 2)

Table 2: Number of partners

\begin{tabular}{|c|c|c|c|}
\hline \multirow[t]{9}{*}{ Number of lifetime partners } & 1 & 663 & $51.4 \%$ \\
\hline & 2 & 254 & $19.7 \%$ \\
\hline & $3-5$ & 69 & $5.3 \%$ \\
\hline & $6-10$ & 35 & $2.7 \%$ \\
\hline & $11-20$ & 37 & $2.9 \%$ \\
\hline & $21-50$ & 29 & $2.2 \%$ \\
\hline & $51-100$ & 27 & $2.1 \%$ \\
\hline & $>100$ & 176 & $13.6 \%$ \\
\hline & Total & 1290 & $100 \%$ \\
\hline \multicolumn{4}{|c|}{ Number of lifetime partners (summary) } \\
\hline & One & 663 & $51.4 \%$ \\
\hline & More than one & 627 & $48.6 \%$ \\
\hline & Total & 1290 & $100 \%$ \\
\hline \multicolumn{4}{|l|}{$\begin{array}{l}\text { Number of partners } \\
\text { during last } 3 \text { months }\end{array}$} \\
\hline & 1 & 813 & $62.5 \%$ \\
\hline & 2 & 60 & $4.6 \%$ \\
\hline & 3 & 17 & $1.3 \%$ \\
\hline & 4 & 10 & $0.8 \%$ \\
\hline & $\geq 5$ & 232 & $17.8 \%$ \\
\hline & None & 168 & $12.9 \%$ \\
\hline & Total & 1300 & $100 \%$ \\
\hline \multirow[t]{3}{*}{ last 3 months (summary) } & One & 813 & $71.8 \%$ \\
\hline & More than one & 319 & $28.2 \%$ \\
\hline & Total & 1132 & $100 \%$ \\
\hline
\end{tabular}


Prevalence of sexually transmitted diseases

Over one quarter $(28.3 \%)$ of the sample did not have identifiable sexually transmitted diseases $(20.2 \%$-no illness, $7.6 \%$-non STD illnesses, $0.5 \%$-uncertain).
HIV was positive in $1.9 \%(25)$ of women in the sample. Majority of the sample $(85 \%)$ did not have a history of STD (Table 3)

Table 3: Prevalence of STDs in the sample

\begin{tabular}{|c|c|c|c|}
\hline Current STD diagnosis & No illness & 263 & $20.2 \%$ \\
\hline \multirow[t]{16}{*}{$(n=1300)$} & HIV positive & 25 & $1.9 \%$ \\
\hline & Gonorrhoea & 16 & $1.2 \%$ \\
\hline & Early syphilis & 15 & $1.2 \%$ \\
\hline & Late syphilis & 159 & $12.2 \%$ \\
\hline & Genital Herpes & 142 & $10.9 \%$ \\
\hline & Chlamydia genital infections & 2 & $0.2 \%$ \\
\hline & Non gonococcal cervicitis & 238 & $18.3 \%$ \\
\hline & Trichomonaisis & 26 & $2.0 \%$ \\
\hline & Genital warts & 112 & $8.6 \%$ \\
\hline & Scabies & 7 & $0.5 \%$ \\
\hline & Candida vaginitis & 160 & $12.3 \%$ \\
\hline & Bacterial vaginosis & 314 & $24.2 \%$ \\
\hline & Other STDs & 26 & $2.0 \%$ \\
\hline & Non STD genital illnesses & 99 & $7.6 \%$ \\
\hline & Uncertain & 7 & $0.5 \%$ \\
\hline & Total diagnosis & 1611 & $123.9 \%$ \\
\hline
\end{tabular}

Counts and percentages are not mutually exclusive

\section{Pap smear abnormalities}

All forms of Pap smear abnormalities

Prevalence of all forms of abnormalities in satisfactory Pap smears was $24.2 \%(315 / 1300)$. HPV changes reported in $0.6 \%$ (7) of women as isolated changes or combined with CIN 1 or CIN 2 changes. Identified causes of majority of Pap smear abnormalities in STD clinic settings were the presence of an infection or inflammation i.e. candida$3.4 \%$, bacterial vaginosis- $3.5 \%$, and non specific inflammation-15.1\%. (Table 4) 
Table 4: Distribution of all forms of Pap smear abnormalities

\begin{tabular}{|c|c|c|c|}
\hline Prevalence of all forms of & NILM (considered as normal) & 985 & $75.8 \%$ \\
\hline \multirow[t]{16}{*}{ Pap smear abnormalities } & TV & 1 & $0.1 \%$ \\
\hline & Candida & 44 & $3.4 \%$ \\
\hline & Bacterial vaginosis & 45 & $3.5 \%$ \\
\hline & Non-specific inflammation & 196 & $15.1 \%$ \\
\hline & HPV changes & 2 & $0.2 \%$ \\
\hline & $\mathrm{CIN} 1$ & 13 & $1.0 \%$ \\
\hline & CIN 1 and HPV changes & 3 & $0.2 \%$ \\
\hline & HSIL & 1 & $0.1 \%$ \\
\hline & $\mathrm{CIN} 2$ & 3 & $0.2 \%$ \\
\hline & CIN 2 and HPV changes & 2 & $0.2 \%$ \\
\hline & Glandular cell atypia & 2 & $0.2 \%$ \\
\hline & Endocervical glandular cell atypia & 1 & $0.1 \%$ \\
\hline & Glandular cell atypia not & & \\
\hline & otherwise specified & 1 & $0.1 \%$ \\
\hline & Squamous/glandular malignancy & 1 & $0.1 \%$ \\
\hline & Total & 1300 & $100 \%$ \\
\hline \multicolumn{4}{|l|}{ Prevalence of all forms of } \\
\hline \multirow[t]{3}{*}{ abnormal Pap smears } & Normal Pap smears & 985 & $75.8 \%$ \\
\hline & Abnormal Pap smears & 315 & $24.2 \%$ \\
\hline & Total & 1300 & $100 \%$ \\
\hline
\end{tabular}

NILM=Negative for intraepithelial lesion or malignancy, TV=Trichomonas vaginalis, HPV=Human papillomavirus, $C I N=$ Cervical intraepithelial neoplasia, $H S I L=H i g h$ grade squamous intraepithelial lesion

Cervical cytological abnormalities (2001 Bethesda abnormal cytology)

The prevalence of cervical cytological abnormalities was $2.2 \%$. One case of squamous/glandular malignancy was found out of 1300 women who underwent Pap smear testing accounting for $0.077 \%$ prevalence (Table 5) 
Table 5: Prevalence of cytological changes

\begin{tabular}{|llrr|}
\hline & & & \\
Prevalence of categories of & NILM & 1271 & $97.8 \%$ \\
cytological premalignant & LSIL & 18 & $1.4 \%$ \\
abnormalities according to & HSIL & 6 & $0.5 \%$ \\
the 2001 Bethesda system & Glandular cell atypia & 4 & $0.3 \%$ \\
& Squamous/glandular malignancy & 1 & $0.1 \%$ \\
\cline { 2 - 4 } & Total & 1300 & $100 \%$ \\
\hline Summary of cytological & 2001 Bethesda - Normal & 1271 & $97.8 \%$ \\
abnormalities & 2001 Bethesda - Abnormal & 29 & $2.2 \%$ \\
\hline
\end{tabular}

NILM=Negative for intraepithelial lesion or malignancy, TV=Trichomonas vaginalis, HPV=Human papillomavirus, CIN=Cervical intraepithelial neoplasia, HSIL=High grade squamous intraepithelial lesion

Data were compared between the groups of normal (NILM) cytology and abnormal cytology. However, difference between the groups in univariate and none of the tested variables showed a significant multivariale analysis (Table 6) 
Table 6: Comparison of characteristics between patients with abnormal and normal cytological changes

\begin{tabular}{|c|c|c|c|c|c|c|}
\hline \multirow[b]{2}{*}{$\begin{array}{l}\text { Variables of } \\
\text { interest }\end{array}$} & \multirow{2}{*}{\multicolumn{2}{|c|}{ Values of interest }} & \multicolumn{2}{|c|}{ Clinic attendees with } & \multirow[b]{2}{*}{ Total } & \multirow[b]{2}{*}{$\begin{array}{r}\text { Significance } \\
\quad(a ́=0.05)\end{array}$} \\
\hline & & & $\begin{array}{r}\text { Negative for } \\
\text { intraepithelial } \\
\text { lesion or } \\
\text { malignancy (NLM) }\end{array}$ & $\begin{array}{r}\text { Premalignant/ } \\
\text { malignant } \\
\text { cytological } \\
\text { changes } \\
\end{array}$ & & \\
\hline \multirow[t]{3}{*}{ Age } & & years & 682 & 11 & 693 & \multirow{3}{*}{$P=0.093$} \\
\hline & & years & 589 & 18 & 607 & \\
\hline & & Total & 1271 & 29 & 1300 & \\
\hline \multirow[t]{3}{*}{ Age at coitarche } & $<2$ & years & 621 & 12 & 633 & \multirow{3}{*}{$P=0.485$} \\
\hline & $\geq 2$ & years & 633 & 16 & 649 & \\
\hline & & Total & 1254 & 28 & 1282 & \\
\hline \multirow[t]{4}{*}{ Marital status } & Single/Never I & arried & 113 & 2 & 115 & \multirow{4}{*}{$P=0.927$} \\
\hline & Married/Living t & gether & 804 & 19 & 823 & \\
\hline & Widow/Separated/D & rorced & 354 & 8 & 362 & \\
\hline & & Total & 1271 & 29 & 1300 & \\
\hline \multirow{3}{*}{$\begin{array}{l}\text { Occupation as } \\
\text { sex workers and } \\
\text { non-sex workers }\end{array}$} & Direct/ indirect sex & orkers & 278 & 7 & 285 & \multirow{3}{*}{$P=0.775$} \\
\hline & & thers & 990 & 22 & 1012 & \\
\hline & & Total & 1268 & 19 & 1297 & \\
\hline \multirow{3}{*}{$\begin{array}{l}\text { Current } \\
\text { contraceptive } \\
\text { users }\end{array}$} & Hormonal contraceptiv & users & 191 & 2 & 193 & \multirow{3}{*}{$P=0.223$} \\
\hline & Others including no & users & 1080 & 27 & 1107 & \\
\hline & & Total & 1271 & 29 & 1300 & \\
\hline \multirow{3}{*}{$\begin{array}{l}\text { Number of } \\
\text { lifetime partners }\end{array}$} & & 1 & 647 & 16 & 663 & \multirow{3}{*}{$P=0.681$} \\
\hline & & $>1$ & 614 & 13 & 627 & \\
\hline & & Total & 1261 & 29 & 1290 & \\
\hline \multirow{3}{*}{$\begin{array}{l}\text { Number of } \\
\text { partners during } \\
\text { last } 3 \text { months }\end{array}$} & & 1 & 795 & 18 & 813 & \multirow{3}{*}{$P=0.956$} \\
\hline & & $>1$ & 476 & 11 & 487 & \\
\hline & & Total & 1271 & 29 & 1300 & \\
\hline \multirow{14}{*}{$\begin{array}{l}\text { Current } \\
\text { STD }\end{array}$} & \multirow{6}{*}{ Genital warts } & Yes & 25 & 0 & 25 & \multirow{3}{*}{$P=0.446$} \\
\hline & & No & 1246 & 29 & 1275 & \\
\hline & & Total & 1271 & 29 & 1300 & \\
\hline & & Yes & 110 & 2 & 112 & \multirow{3}{*}{$P=0.739$} \\
\hline & & No & 1161 & 27 & 1188 & \\
\hline & & Total & 1271 & 29 & 1300 & \\
\hline & \multirow{3}{*}{ Genital Herpes } & Yes & 139 & 3 & 142 & \multirow{3}{*}{$P=0.920$} \\
\hline & & No & 1132 & 26 & 1158 & \\
\hline & & Total & 1271 & 29 & 1300 & \\
\hline & \multirow{5}{*}{$\begin{array}{r}\text { Chlamydial } \\
\text { Non-gonococcal } \\
\text { cervicitis }\end{array}$} & Yes & 238 & 2 & 240 & \multirow{5}{*}{$P=0.105$} \\
\hline & & No & 1033 & 27 & 1060 & \\
\hline & & Total & 1271 & 29 & 1300 & \\
\hline & & No & 1255 & 28 & 1283 & \\
\hline & & Total & 1271 & 29 & 1300 & \\
\hline
\end{tabular}




\section{Discussion}

An abnormal Pap smear indicates an infection, inflammation or cervical cytological abnormality. In this study, it has been found that $24.2 \%$ of the sample had some form of Pap smear abnormality whereas in the national sample of well woman clinic attendees $(\mathrm{N}=66,799)$ in 2010 , it was $8.8 \%$. (7) The study done in 1986 at the same STD clinic showed that the prevalence of cytological abnormality was $13.4 \%$ (47/350) and all forms of abnormalities were $49.4 \%$ $(173 / 350)$. (6) In a study conducted in Turkey in a primary health care setting among 332 married women, $17.7 \%$ of abnormalities were due to infections and $67.2 \%$ were due to reactive cell differences while $1.2 \%$ was due to epithelial cell anomalies. (8) In this study, the prevalence of all forms of Pap smear abnormalities was relatively high due to the concurrent infections and non specific inflammations prevalent in the group.

However, the main focus of Pap smear analysis is to detect the cytological changes that have a potential to progress in to cervical cancer. The interpretation of sample of cervical epithelial cells using the standard Bethesda system provide an evidence based approach to early interventions and prevention of cervical cancer. In this study, the prevalence of cervical cell abnormalities was $2.2 \%$ (LSIL-1.4\%, HSIL- $0.5 \%$, Glandular cell atypia- $0.3 \%$ and squamous/glandular malignancy-0.1\%) while in the well woman clinic (WWC) sample the same figure was $1.9 \%$. A retrospective record based descriptive study conducted in the Colposcopy clinic of the professorial unit of the South Colombo Teaching Hospital among women older than 45 years of age (period 2007-2011) had shown that $14.2 \%(n=269)$ pap smears were abnormal and the total high grade pre malignant cases detected and treated in the Colposcopy clinic was $4 \%$. (9) In the Turkey study in primary health care setting, the epithelial cell abnormalities were seen in $1.2 \%(n=332)$. Pap smear study in an urban STD clinic in Colorado, USA showed that out of 2034 Pap smears 1313 (64.6\%) were negative, $202(9.9 \%)$ were unsatisfactory, 257 $(12.6 \%)$ were atypical, $211(10.4 \%)$ had LSIL, and
$51(2.5 \%)$ had HSIL. (10) A study done among women attending STD clinics in Pune, India showed that $10 \%$ of the HIV sero-negative women and $19.2 \%$ of the HIV sero-positive women had squamous cell abnormality. (11) The proportion of cervical cell abnormalities found in this study is relatively low compared with the studies quoted; this may be due to the differences of distribution of determinants in various settings.

One case of malignant lesion was found among 1300 STD clinic attendees and the prevalence of malignancy was found to be $0.077 \%$. In 2010 the WWC sample $(\mathrm{N}=66,799)$ prevalence of cervical cancer was $0.093 \%$. However, according to the Cancer Registry in Sri Lanka, the incidence for cervical cancer for the year 2005 was reported as 16/100,000 population (0.016). (2) In general, high risk regions for cervical cancer are Eastern and Western Africa (ASR greater than 30 per 100,000). Rates are lowest in Western Asia, Northern America and Australia/New Zealand (ASR less than 6 per 100,000 . (12) The prevalence of cervical malignancy revealed in this study need to be strengthened with supportive studies with large samples.

Furthermore, the characteristics of STD clinic attendees with and without cervical cytological changes were compared in the univariate and multivariate model with regard to age, age at coitarche, marital status, occupation as sex work, hormonal contraceptive use, number of partners (life time and last 3 months), current status of STD (HIV, genital warts, genital herpes non-gonococcal cervicitis (table 6), but none of the tested variables showed a relationship. In the study done in STI clinics in Pune, India showed that, having more than one life time partners and presence of STDs were also significantly associated with Pap smear cytological abnormalities in univariate analysis. In the same study multivariate model showed both STD and HIV infection are more likely to have abnormal Pap smears. (11) In the study done in Colorado, USA, cellular atypia was associated with genital warts while LSIL with younger age, black race and genital warts in multivariate analysis. (10) It seems in this study 
that there is no significant difference between the group with or without cytological changes.

\section{Conclusions}

All forms of Pap smear abnormalities in STD clinic attendees are relatively high $(24.2 \%)$ due to the concurrent infections and inflammation. The prevalence of cervical cytological abnormalities was $2.2 \%$. Prevalence of cervical cancer in the (STD clinic) sample was $0.077 \%$ which needs to be further tested for the strength of finding. In comparison of the two groups with and without cytological abnormalities, it was found that there were no significant differences between the characteristics tested. No predictors for cervical cell abnormalities were identified in multivariate analysis.

\section{Acknowledgements}

Dr C D Wickramasuriya, Consultatnt Venereologist, National STD/AIDS Control Programme, Sri Lanka. Dr Sriyani Nanayakkara, Histopathologist, De Soysa Maternity Hospital, Colombo. Mr. Suchira Suranga, M\&E officer, Family Planning Association of Sri Lanka. Mrs R A W Rajapakshe, Nursing Officer, National STD/AIDS Control Programme, Sri Lanka

\section{Conflict of interest}

No conflict of interests

\section{Funding}

No external funding

\section{References}

1. World Health Organization. Comprehensive cervical cancer prevention and control: a healthier future for girls and women Switzerland: World Health Organization; 2013.

\section{National Cancer Control Programme. Cancer}

Registry: Cancer Incidence Data: Sri Lanka Year 2001-2005 Colombo: National Cancer Control

Programme; 2009.
3. National Cancer Institute at the National Institute of Health, US. [Online].; Nov 2010 [cited 2013 08 11. Available from: http://www.cancer.gov.

4. Twombly R. New Pap Test Termnology. Management Guidelines Published. Journal of · National Cancer Institute. 2002; 94(12).

5. DD. D. Cervical cytology classification and the Bethesda System. Cancer Journal. 2003 Sep-Oct; 9(5).

6. Abeyewickreme I. Cervical cytology screening in a sexually transmitted diseases clinic for the first time in Sri Lanka. Genitourinary Medicine. 1989; 65: p. 98-102.

7. Annual Report on Family Health 2010. Colombo: Ministry of Health, Family Health Bureau; 2010. Report No.: ISN 978-955-1503-12-3.

8. Mehmetoglu HC, Sadikoglu G, Ozcakir A, Bilgel N. Pap smear screening in the primary health care setting: A study from Turkey. N Am J Med Sci. 2010 October; 2(10).

9. Jayalath GKC, Jayawardane MAMM, Wijewardena MGDG, Fernandopulle RC, Fernando TAN. Analysis of pap smear and colposcopy results of post reproductive age women at a tertiary care centre in Sri Lanka. In Annual Scientific Conference of Menopause Society of Sri Lanka; 2011; Colombo. p. 34.

10. Shlay JC, McGill WL, Masloboeva HA, Douglas JM Jr. Pap smear screening in an urban STD clinic. Yield of screening and predictors of abnormalities. Sex Transm Dis. 1988 Oct; 25(9).

11. Joshi S, Chandorkar A, Krishnan G, Walimbe A, Gangakhedkar R, Risbud A, Jadhav V, Bollinger $\mathrm{R}$, Mehendale S. Cervical intraepithelial chages \& HIV infection in women attending sexually transmitted diseases clinics in Pune, India. Indian J Med Res. 2001 May; 113.

12.GLOBOCAN 2008. [Online];; 2008 [cited 2013 September 15. Available from: http:// globocan.iarc.fr/. 